\title{
FORCED OSCILLATION OF FRACTIONAL PARTIAL DIFFERENTIAL EQUATIONS WITH DAMPING TERM
}

\section{HUANHUAN KONG AND RUN XU}

Abstract. In this paper, the forced oscillation of fractional partial differential equations of the form

$$
\begin{aligned}
D_{+, t}^{1+\alpha} u(x, t)+p(t) D_{+, t}^{\alpha} u(x, t)= & a(t) \Delta u(x, t)+\sum_{i=1}^{m} a_{i}(t) \Delta u\left(x, t-\tau_{i}\right) \\
& -q(x, t) \int_{0}^{t}(t-\xi)^{-\alpha} u(x, \xi) d \xi+f(x, t),(x, t) \in \Omega \times R_{+} \equiv G
\end{aligned}
$$

are investigated, and some examples are given to illustrate the useful of our results.

Mathematics subject classification (2010): 34C10.

Keywords and phrases: Forced, oscillation, fractional, partial differential equations.

\section{REFERENCES}

[1] R. Courant and D. Hilbert, Methods of Mathematical Physic, vol. 1, Interscience, New York, NY, USA, 1966.

[2] I. Podlubny, Fractional Differential Equations, Academic Press Inc., San Diego, 1999.

[3] A. A. Kilbas, H. M. SRivastava, J. J. Trujillo, Theory and Applications of Fractional Differential Equations, Elsevier Science B. V., Amsterdam, 2006.

[4] S. DAS, Functional Fractional Calculus for System Identification and Controls, Springer, Berlin, 2008.

[5] S. Abbas, M. Benchohra, G. M. N'GuéréKata, Topics in Fractional Differential Equations, Springer, New York, 2012.

[6] Y. ZHou, Basic Theory of Fractional Differential Equations, World Scientific Publishing Co. Pte. Ltd., Hackensack, 2014.

[7] H. JAfari, M. NaZari, D. Baleanu, C. M. Khalique, A new approach for solving a system of fractional partial differential equations, Comput. Math. Appl. 66 (2013), 838-843.

[8] C. CHEN, Y. L. JiANG, Lie group analysis method for two classes of fractional partial differential equations, Commun. Nonlinear Sci. Numer. Simul. 26 (2015), 24-35.

[9] P. Prakash, S. Harikrishnan, J. J. Nieto, Oscillation of a time fractional partial differential equation, Electron. J. Qual. Theory Diff. Equ. 15 (2014), 1-10.

[10] P. Prakash, S. HARIKRISHNAN, M. BENCHOHRA, Oscillation of certain nonlinear fractional partial differential equation with damping term, Appl. Math. Lett. 43 (2015), 72-79.

[11] S. HARIKRISHNAN, P. PrakASH, J. J. NiETO, Forced oscillation of solutions of a nonlinear fractional partial differential equation, Appl. Math. Comput. 254 (2015), 14-19.

[12] W. N. LI, Forced Oscillation Criteria for a class of Fractional Partial Differential equations with damping term, Hindawi Publishing Corporation Mathematical Problems in Engineering Volume 2015, Article ID 410904, 6 pages.

[13] W. N. LI, W. H. SHENG, Oscillation properties for solutions of a kind of partial fractional differential equations with damping term, J. Nonlinear Sci. Appl. 9 (2016), 1600-1608.

[14] B. ZHENG, Exact solutions for some fractional partial differential equations by the $\left(G^{\prime} / G\right)$ method, Math. Probl. Eng. 2013 (2013), 13 pages. 
[15] B. ZHENG, Q. FENG, A new approach for solving fractional partial differential equations in the sense of the modified Riemann-Liouville derivative, Math. Probl. Eng. 2014 (2014), 7 pages.

[16] J. C. YANG, A. P. LiU, Forced Oscillation of nonlinear fractional differential equations with damping term, Advances in Difference Equations, Vol. 2015, 7 pages.

[17] R. XU, Oscillation Criteria for Nonlinear Fractional Differential Equations, Journal of Applied Mathematics, Volume 2013, Article ID 971357, 7 pages.

[18] R. XU, Y. ZHANG, Generalized Gronwall fractional summation inequalities and their applications, Journal of Inequalities and Applications 2015, 242 (2015).

[19] R. Xu, F. Meng, Some New Weakly Singular Integral Inequalities and Their Applications to Fractional Differential Equations, Journal of Inequalities and Applications 2016, 78 (2016), 1-16. 